\title{
Analysis of Higher Education Readiness in Medan City in Implementing Risk Based Internals Audit to Realize Good University Governance
}

\author{
Muhammad Ridha Habibi ${ }^{1 *}$, OK Sofyan Hidayat ${ }^{1}$, Taufik Hidayat ${ }^{1}$, Esa \\ Setiana ${ }^{1}$, Nisha Marina ${ }^{1}$ \\ ${ }^{l}$ State University of Medan \\ "Corresponding author. Email: habibi79aksi@gmail.com
}

\begin{abstract}
In the past decade, there has been a paradigm shift in financial management in certain types of work units in government agencies and ministries to become more flexible, such as hospitals and universities. This flexibility is given based on the characteristics of the type of service provided because it demands faster services in addition to the work unit also managing public funds. To achieve good corporate governance, the Ministry of Education and Culture (Kemendikbud) of the Republic of Indonesia is trying to encourage the establishment of an Internal Control Unit (SPI) at the university level. The existence of SPI as a whole in every work unit of the Ministry of Education and Culture is regulated in the Regulation of the Minister of National Education of the Republic of Indonesia No. 47 of 2011 concerning Internal Supervisory Units within the Ministry of National Education. It should be understood that every internal auditor must have a paradigm that is in line with the goals of the organization. The work methods and procedures must be adjusted to the demands of management or stakeholders. This is where one form of the function of the internal auditor, which is to help management minimize risk. This has led to the emergence of the concept of risk-based internal auditing (RBIA), which we usually call risk-based auditing or other adapted terms. RBIA is a methodology that combines an organization's risk management framework with internal audit. Through this methodology, internal auditors ensure that the organization's risk management processes are implemented to manage risk effectively. This research aims to analyze the Readiness of Higher Education in Medan City in Implementing Risk-Based Internals to Realize Good University Governance. The Result is The level of readiness for implementing AIBR at PTN in Medan City obtained a score of X $=4.23$ which means that it is ready to implement AIBR but still needs a slight improvement.
\end{abstract}

Keywords: Higher Education Readiness, Risk-based Internal Audit, Good University Governance.

\section{INTRODUCTION}

The Ministry of Finance gives Several State Universities (PTN) in Indonesia flexibility in financial management. It grants PTNs the authority to manage public funds the status of a Public Service Agency (BLU). The regulation about Work units with the level of BLU in the Republic of Indonesia Government Regulation No. 23 of 2005 has been amended through Government Regulation of the Republic of Indonesia No. 74 of 2012 concerning Financial Management of Public Service Agencies. With BLU status, the risk in management is getting higher, so it is crucial to implement a risk-based internal audit.

Who should understand that every internal auditor must have a paradigm that is in line with the organization's goals? Who must adapt ways and work procedures to the demands of management or stakeholders? Also, leadership is essential to manage how to achieve the goals that have been previously determined effectively; beyond that, management must also be aware of the risks that exist in each choice of the way they will choose. But it is clear that what 
the existing risk management wants can be reduced to a minimum even though management knows that it cannot eliminate the risk. This refers to one form of the internal auditor's function is to help management minimize risk. This has led to the emergence of the concept of risk-based internal auditing (RBIA), what we usually call a risk-based audit or other customized terms. RBIA is a methodology that combines an organization's risk management framework with internal audits. Through this methodology, internal auditors ensure that the organization's risk management processes manage risk effectively.

\section{LITERATURE REVIEW}

\subsection{Theoretical Framework}

Goal-Setting Theory, states that employees who have a high commitment to goals will affect managerial performance. Commitment to goals makes a person committed to achieving goals and can control specific goals, which in turn will improve individual performance. Managers who have a high level of commitment to goals will have a positive outlook and will try to do their best to achieve their goals so that, in the end, it will have an impact on improving managerial performance.

\subsection{Good University Governance}

Simple Good University Governance (GUG) can be viewed as the application of the basic principles of the concept "good governance" in systems and processes governance in higher education institutions through various adjustments made based on values that must be upheld in the administration of higher education in particular and education in general. Good University Governance is a concept that applies the basic principles of Good governance such as transparency, accountability, responsibility, independence, and fairness that need to be applied by every university to create a quality university.

\subsection{Risk Based Internal Audit}

According to the IIA (Insurance Institute Agents Association), risk-based auditing is a methodology that links internal audit with all risk management frameworks that allow the internal audit process to gain reasonable assurance that risk management has been adequately managed in relation to acceptable risk (risk appetite). Risks that are above the risk appetite are considered a threat to a company in achieving its goals.

\subsection{Readiness Level}

The level of readiness, several previous studies have tried to develop several models to test this level of readiness (readiness). For example, four components to measure this level of readiness, namely technology readiness, innovation readiness, the human factor (people factor), and self-development).

\section{RESEARCH METHODS}

\subsection{Location and Time}

To obtain data in this study, the authors conducted research at universities in the city of Medan. The time of the study was carried out from May to November 2021. The selection of the sample area in Medan was based on the ability of researchers to conduct field surveys.

\subsection{Population and Sample}

The population is a generalization area consisting of objects/subjects that have certain qualities and characteristics that are applied by researchers to be studied and then drawn conclusions. The population in this study were all PTN and PTS in the city of Medan. The sample is part of the number and characteristics possessed by the population. The sample used in this study were several PTN and PTS that were willing to be used as research sites. The research subjects in this study consisted of members of the SPI and AMI/SPMI at the university. The sampling technique for this research is simple random sampling by taking into account the resources and willingness of the school. It is said randomly without regard to the existing strata in the population.

\section{RESEARCH RESULT}

\subsection{Respondent Demographics}

In this study, 31 respondents participated. Of the 35 respondents, only 31 questionnaires from respondents were processed. This happened because two sets of questionnaires were filled out incompletely, and two sets of questionnaires were filled out by people who were not the object of this study. So the data processed in this study were 31 respondents. The following is the distribution of respondents classified based on the name of the university (PT), position at PT, educational background, and length of work. Most respondents came from Panca Budi University, with a total of $25.7 \%$ of respondents and at least $2.9 \%$ from Unimed 
and USU. This is not surprising because there are very few SPI members from the two PTNs. The majority of the respondents in this study were members of the SPI, as many as $82.9 \%$. This is very reasonable because the composition of the members is more than the other components. The majority of respondents in this study have an accounting education background, as much as $74.3 \%$. This is very reasonable because accounting competence is needed in the implementation of general audits. The majority of the respondents in this study have worked for more than five years, as much as $48.6 \%$. This is in line with the target of our respondents, namely more experienced auditors.

\subsection{Higher Education Level of Readiness in AIBR Implementation}

Table 1. Technology factor calculation

\begin{tabular}{|c|c|c|c|c|}
\hline aspect & Point & Total & Mean & \begin{tabular}{|c} 
Average \\
Score \\
\end{tabular} \\
\hline \multirow{3}{*}{ Resource } & Q3 & 131 & 4,22 & \multirow{3}{*}{4,16} \\
\hline & Q4 & 129 & 4,16 & \\
\hline & Q5 & 127 & 4,09 & \\
\hline \multirow{3}{*}{ Skills } & Q7 & 138 & 4,45 & \multirow{3}{*}{4,34} \\
\hline & Q8 & 135 & 4,35 & \\
\hline & Q9 & 136 & 4,38 & \\
\hline \multirow{5}{*}{ Attitude } & Q10 & 133 & 4,29 & \multirow{5}{*}{4,27} \\
\hline & Q15 & 128 & 4,13 & \\
\hline & Q18 & 131 & 4,23 & \\
\hline & Q19 & 134 & 4,32 & \\
\hline & Q34 & 136 & 4,38 & \\
\hline \multicolumn{2}{|c|}{ AVERAGE FACTORS } & & & 4,26 \\
\hline
\end{tabular}

From the table above, it can be seen that the average technology factor score is 4.26. This means that from a technological factor, universities are ready for AIBR deployment but need a little improvement.
Table 2. Innovation factor calculation

\begin{tabular}{|c|c|c|c|c|}
\hline aspect & Point & Total & Mean & $\begin{array}{c}\text { Average } \\
\text { Score }\end{array}$ \\
\hline Resource & Q30 & 135 & 4,35 & 4,35 \\
\hline \multirow{2}{*}{ Skills } & Q6 & 134 & 4,32 & \multirow{2}{*}{4,29} \\
\hline & Q28 & 132 & 4,26 & \\
\hline \multirow{5}{*}{ Attitude } & Q11 & 133 & 4,29 & \multirow{5}{*}{4,21} \\
\hline & Q12 & 127 & 4,09 & \\
\hline & Q17 & 126 & 4,06 & \\
\hline & Q19 & 138 & 4,45 & \\
\hline & Q35 & 129 & 4,16 & \\
\hline \multicolumn{2}{|c|}{ AVERAGE FACTORS } & & & 4,28 \\
\hline
\end{tabular}

From the table above, it can be seen that the average score of the innovation factor is 4.28 . This means that from a technological factor, universities are ready for AIBR deployment but need a little improvement.

Table 3. Human factor calculation

\begin{tabular}{|c|c|c|c|c|}
\hline aspect & Point & Total & Mean & $\begin{array}{c}\text { Average } \\
\text { Score } \\
\end{array}$ \\
\hline \multirow{5}{*}{ Resource } & Q1 & 137 & 4,42 & \multirow{5}{*}{4,19} \\
\hline & Q2 & 131 & 4,22 & \\
\hline & Q24 & 130 & 4,19 & \\
\hline & Q25 & 120 & 3,87 & \\
\hline & Q29 & 132 & 4,25 & \\
\hline \multirow{2}{*}{ Skills } & Q26 & 124 & 4 & \multirow{2}{*}{4,14} \\
\hline & Q27 & 133 & 4,29 & \\
\hline \multicolumn{2}{|c|}{ AVERAGE FACTORS } & & & 4,16 \\
\hline
\end{tabular}

From the table above, it can be seen that the average human factor score is 4.16. This means that from a technological factor, universities are ready for AIBR deployment but need a little improvement.

Table 4. Self-development factor calculation

\begin{tabular}{|c|c|c|c|c|}
\hline aspect & Point & Total & Mean & $\begin{array}{c}\text { Average } \\
\text { Score }\end{array}$ \\
\hline \multirow{3}{*}{ Resource } & Q20 & 131 & 4,22 & \multirow{3}{*}{4,32} \\
\hline & Q21 & 133 & 4,29 & \\
\hline & Q22 & 138 & 4,45 & \\
\hline \multirow{2}{*}{ Skills } & Q36 & 128 & 4,12 & \multirow{2}{*}{4,075} \\
\hline & Q14 & 125 & 4,03 & \\
\hline \multirow{6}{*}{ Attiude } & Q16 & 131 & 4,22 & \multirow{6}{*}{4,26} \\
\hline & Q31 & 132 & 4,25 & \\
\hline & Q32 & 133 & 4,29 & \\
\hline & Q33 & 136 & 4,38 & \\
\hline & Q23 & 131 & 4,22 & \\
\hline & Q13 & 131 & 4,22 & \\
\hline \multicolumn{2}{|c|}{ AVERAGE FACTORS } & & & 4,22 \\
\hline
\end{tabular}

From the table above, it can be seen that the average technology factor score is 4.22 . This means that from 
the self-development factor, higher education is ready for AIBR deployment but needs a little improvement.

Based on the average score above and refer to Aydin \& Tasci's ELR Model Value and Category Scale Table.

Table 5. Aydin \& Tasci ELR Model Value and Category Scale

\begin{tabular}{|l|l|}
\hline \multicolumn{1}{|c|}{ Value Range } & \multicolumn{1}{c|}{ Category } \\
\hline $1 \times 2.6$ & Not ready, needs a lot of upgrades \\
\hline 2.6 X 3.4 & Not ready, needs a little upgrade \\
\hline 3.4 X 4.2 & Ready, but needs a little upgrade \\
\hline 4.2 X 5 & Ready, AIBR implementation can be continued \\
\hline
\end{tabular}

\section{CONCLUSIONS AND RECOMMENDATIONS}

\subsection{Conclusions}

The conclusions from this research are as follows:

The level of readiness for implementing AIBR at PTN and PTS in Medan City obtained a score of $\mathrm{X}=4.23$ which means that it is ready to implement AIBR but still requires improvements in technological, innovation, human, and self-development factors.

\subsection{Recommendations}

Universities in Medan City need to improve its technological, innovation, human, and selfdevelopment factors in university, both from existing individual skills and attitudes. It is important for every university leader to pay attention to this because the attitude to support the AIBR program is very much needed from all internal universities. In addition, skills to map and mitigate risks are indispensable in the implementation of AIBR.

\section{AUTHORS' CONTRIBUTIONS}

The authors'contribution of researchers in this research is to develop risk maps and risk mitigation in universities.

\section{ACKNOWLEDGMENTS}

The author would like to thank all parties who have participated in the completion of this research. So that this research can be entered into the proceedings. Hopefully, this article is useful for all parties.

\section{REFERENCES}

[1] Badara, Mu'azu Saidu, The role oflnternal Auditors in Ensuring effective Financial Control at Local Government Level: Case of Alkaleri. 2012.

[2] Ayagre, The Adoption of Risk Based Internal Auditing in Developing Countries, European Journals of Accounting Auditing and Finance Research Vol.2,No.7, 2014, pp.52-65

[3] Coetzee, Contribution of internal auditing to risk management: perceptions of public sector senior management, Journal of Public Sector Management, Vol. 29 Iss 4. 2016.

[4] Duygu, Risk Based Internal Auditing and Risk Assessment Process, European Journal of Accounting Auditing and Fianance Research Vol.2, No.7, 2014, pp.1-16

[5] Ita Megasari, Audit BerbasisRisiko dalam Pengujian Atas Pengendalian Internal pada Siklus Pendapatan(Studi Kasus padaFakultas Psikologi - Universitas Surabaya), Jurnal Ilmu \& Riset Akuntansi Vol. 3 No. 11. 2014.

[6] Untari, Pengaruh Peran Satuan Pengawasan Intern (Spi) Dan Penerapan Internal Control Terhadap Pencapaian Good University Governance (Gug). Universitas Islam Negeri Syarif Hidayatullah. Jakarta. 2015.

[7] Williem F Messier ,Jasa Audit dan Assurance, Edisi 8, Salemba Empat, Jakarta, 2014. 